\title{
Methane emission factor of open deposits used to store swine slurry in Southern Brazil
}

\author{
Luana Goulart Sardá(1), Martha Mayumi Higarashi(2), Rodrigo da Silveira Nicoloso(2), \\ Paulo Armando Victória de Oliveira(2), Camila Falkoski( ${ }^{(3)}$, \\ Stephanie Mayara Siega Ribeiro ${ }^{(3)}$ and Arlei Coldebella ${ }^{(2)}$
}

\begin{abstract}
(1)Universidade Federal de Santa Catarina, Departamento de Engenharia Química e de Engenharia de Alimentos, Campus Universitário Reitor João David Ferreira Lima, CEP 88040-900 Florianópolis, SC, Brazil. E-mail: luanasarda@hotmail.com (2)Embrapa Suínos e Aves, Rodovia BR-153, Km 110, Vila Tamanduá, CEP 89715-899 Concórdia, SC, Brazil. E-mail: martha.higarashi@embrapa.br, rodrigo.nicoloso@embrapa.br, paulo.armando@embrapa.br, arlei.coldebella@embrapa.br ${ }^{(3)}$ Universidade do Contestado, Engenharia Ambiental e Sanitária, Rua Victor Sopelsa, no 3.000, CEP 89711-330 Concórdia, SC, Brazil. E-mail: camila.falkoski@hotmail.com, teeffi_m@hotmail.com
\end{abstract}

\begin{abstract}
The objective of this work was to contribute to the establishment of a baseline for the methane emission factor for the management of swine manure, considering the current practice of raw manure storage in two open deposits in parallel, in Southern Brazil. Methane $\left(\mathrm{CH}_{4}\right)$ emissions were continuously measured in three PVC tanks of $3 \mathrm{~m}^{3}$, during 180 days, in the summer. As the content of volatile solids of pig slurry ran out in approximately 130 days, the $\mathrm{CH}_{4}$ emission factor was calculated as $\mathrm{B}_{0}=0.48 \mathrm{~m}^{3} \mathrm{~kg}^{-1} \mathrm{VS}$. Although this value is higher than the $\mathrm{B}_{0}$ estimated by Intergovernmental Panel on Climate Change for Latin America $\left(0.29 \mathrm{~m}^{3} \mathrm{~kg}^{-1} \mathrm{VS}\right)$, it is in agreement with the $\mathrm{B}_{0}$ estimated for developed countries $\left(0.45\right.$ and $0.48 \mathrm{~m}^{3} \mathrm{~kg}^{-1} \mathrm{VS}$, for the US and EU, respectively). The graphic of accumulated $\mathrm{CH}_{4}-\mathrm{C}$ emission $\mathrm{x}$ time fitted a sigmoidal, kinetic model $\left(r^{2}=0.998\right)$ that showed a good correlation when tested with the emission data collected from a slurry deposit, under field conditions, in winter. This suggests that the model reproduces the $\mathrm{CH}_{4}$ emission kinetics in the region. By applying the reviewed state law rules (retention time of 50 instead of 120 days), estimates by the sigmoidal equation show that it is possible to reduce in more than $80 \%$ methane gas emission.
\end{abstract}

Index terms: animal production, emission factor, global warming, greenhouse gases, waste management.

\section{Fator de emissão de metano em depósitos abertos utilizados para armazenar dejetos suínos no Sul do Brasil}

Resumo - O objetivo deste trabalho foi estabelecer uma linha de base do fator de emissão de metano para o manejo de dejetos suínos, ao se considerar a prática atual de armazenamento de dejetos sólidos em dois depósitos abertos paralelos, no Sul do Brasil. As emissões de metano $\left(\mathrm{CH}_{4}\right)$ foram medidas continuamente em três tanques de PVC de $3 \mathrm{~m}^{3}$, durante 180 dias, no verão. Como o conteúdo de sólidos voláteis dos dejetos esgotou-se em aproximadamente 130 dias, calculou-se o fator de emissão de $\mathrm{CH}_{4}$ dos dejetos como $\mathrm{B}_{0}=0,48 \mathrm{~m}^{3}$ $\mathrm{kg}^{-1}$ VS. Embora este valor seja superior ao $B_{0}$ estimado pelo Painel Intergovernamental sobre Mudanças Climáticas para a América Latina $\left(0,29 \mathrm{~m}^{3} \mathrm{~kg}^{-1} \mathrm{VS}\right)$, ele está de acordo com o $\mathrm{B}_{0}$ estimado para países desenvolvidos (0,45 e 0,48 $\mathrm{m}^{3} \mathrm{~kg}^{-1} \mathrm{VS}$, para EUA e UE, respectivamente). O gráfico de emissão acumulada de $\mathrm{C}-\mathrm{CH}_{4} \times$ tempo ajustou-se a um modelo cinético sigmoidal $\left(\mathrm{r}^{2}=0,998\right)$, que apresentou boa correlação quando testado com dados coletados de um depósito de dejetos em condições de campo, no inverno. Isto sugere que o modelo reproduz a cinética de emissão do $\mathrm{CH}_{4}$ na região. Pela aplicação das regras revisadas da lei estadual (tempo de retenção de 50 dias, em substituição a 120 dias), as estimativas pela equação sigmoidal mostram que é possível reduzir em mais de $80 \%$ a emissão de gás metano.

Termos para indexação: produção animal, fator de emissão, aquecimento global, gases de efeito estufa, manejo de dejetos.

\section{Introduction}

Brazil is nowadays classified as a newly industrialized country in socioeconomic aspects; however, agriculture still remains as its major source of greenhouse gas (GHG) emission (Brazil, 2010). The contribution of livestock manure management to total national agricultural emissions of $\mathrm{N}_{2} \mathrm{O}$ and $\mathrm{CH}_{4}$ 
worldwide varies, but it can exceed 50\% (Chadwick et al., 2011). In Brazil, agriculture accounts for more than $35 \%$ of all greenhouse gas (GHG) emissions (Cardoso et al., 2016), from which manure management, accounting for $4.9 \%$, is also the primary source of GHG of pig farming (Dennehy et al., 2017).

The management adopted by most part of Brazilian swine facilities consists in storing slurry or liquid manure, in open anaerobic pits outside the animal housing, followed by its spread/incorporation to crops or pasture as organic fertilizer (Kunz et al., 2009; Cherubini et al., 2015). Nonetheless, the law that regulates swine manure management in the major producing region, Santa Catarina state, was reviewed (Santa Catarina, 2014). The main modifications establish a minimum storing time (reduced from 120 to 40 days), and the need of two manure deposits ( $\mathrm{V}=40$ days of production per each) operated in parallel, in order to ensure that the whole manure in the deposit will be kept stored for at least 40 days.

Despite this recent management improvement, the storing/spreading practices have been harshly criticized due to the risks of storage leakages, nutrient surplus applied to the soil and waterbodies eutrophication. Besides, odors and atmospheric emissions of GHG, or hazardous gases, are also environmental issues frequently highlighted (Riaño \& García-González, 2015). In the last years, traditional treatment technologies such as biogas digester and composting have been referred to as promising alternatives to mitigate environmental impact and $\mathrm{CH}_{4}$ emissions from livestock operations (Laguë, 2003; Brown et al., 2008; Tauseef et al., 2013). Based on that, both treatments were included in an environmental policy program called Low-Carbon Agriculture (ABC Program) which supports initiatives that could mitigate GHG from the agricultural sector. The program was created by the Brazilian government in 2010, and it was established in 2012 aimed at helping the country to meet climate goals announced in Copenhagen 2009, when Brazil committed to reduce its gas emissions by $36-39 \%$ by 2020 (Angelo, 2012).

The factor $\mathrm{B}_{0}$ is used to assess the contribution of manure to global warming in different parts of the world, and it was formulated to define the production potential of methane, which depends mainly on animal genetic, feed intake and digestibility (Zeeman $\&$ Gerbens, 2000). $\mathrm{B}_{0}$ also represents the maximum quantity of $\mathrm{CH}_{4}$ which can be produced by $1 \mathrm{~kg}$ of volatile solids (VS) contained in a manure treatment system (Godbout et al., 2010). The Intergovernmental Panel on Climate Change (IPCC) estimated the default emission factor $\mathrm{B}_{0}$ for different parts of the world; however this estimation was based on the values reported in a study conducted under US conditions (Safely et al., 1992; Eggleston et al., 2006). Therefore, the uncertainty of this estimate is very high due to the wide variety of existing animal production systems around the globe.

There are few studies on GHG emissions under Brazilian conditions, either for the baseline management, or the main available treatments. Moreover, the swine production sector is very dynamic, and its technical and legal aspects are constantly being updated. Therefore, there are increasing needs for a better comprehension of the dynamics of gaseous emissions, and of how eventual changes in waste management could impact Brazilian GHG inventory data. This study is part of an effort to quantify changes in $\mathrm{CO}_{2}$ eq emission associated with modifications on the practices adopted for manure management or treatment.

The objective of this work was to improve the understanding of $\mathrm{CH}_{4}$ emission kinetics, and to estimate $\mathrm{B}_{0}$ of swine slurry under Southern Brazil conditions, in order to contribute to the establishment of a baseline of the $\mathrm{CH}_{4}$ emission factor of manure, considering as the baseline management its storage in two open deposits operated in parallel.

\section{Materials and Methods}

The assay was conducted during 180 days, from August 2014 to January 2015 (summer). The apparatus was assembled in triplicate, in a polyethylene greenhouse located in the municipality of Concordia, in the state of Santa Catarina, Brazil $\left(27^{\circ} 18^{\prime} 46^{\prime \prime}\right.$, $51^{\circ} 59^{\prime} 16^{\prime \prime} \mathrm{W}$, at an altitude of $550 \mathrm{~m}$ ).

Each experimental unit consisted of a $3 \mathrm{~m}^{3}$ polyethylene reactor which was fed during eight weeks with fresh raw swine slurry from a growing to finishing facility (Table 1). Samples of manure were collected at each load, and sent to laboratory for the analysis of total nitrogen ( $\mathrm{TN}$ ), ammonium nitrogen $\left(\mathrm{NH}_{4}{ }^{+}-\mathrm{N}\right)$, organic carbon $(\mathrm{OC})$ and volatile solids 
(VS), according to official methods (American Public Health Association, 1998).

The slurry emitting surfaces were covered by dynamic chambers to capture and direct the emitted gases through the $\varnothing=150 \mathrm{~mm}$ exhaust outlet pipes, equipped with fans that kept a continuous average ventilation rate of $114 \pm 7.5 \mathrm{~m}^{3}$ per hour (mean of the three replicates). The air streaming was measured by a hot wire anemometer (Testo 405, Testo SE \& Co. KGaA, Lenzkirch, Germany).

Emissions of $\mathrm{CH}_{4}$ were continuously measured over 180 days using a multipoint sampler connected through Teflon tubes $(\varnothing=4 \mathrm{~mm})$ to six sampling points: the three gas inlets of each dynamic chamber, and their respective exhaust pipes, $50 \mathrm{~cm}$ before the fans. Sampling device (Innova 1309, Air Tech Instruments, Ballerup, Denmark) was programmed to automatically collect gaseous samples from the six points successively, in order to complete the sampling cycle in $20 \mathrm{~min}$, and the $\mathrm{CH}_{4}$ concentration was continuously determined by an infrared photoacoustic gas monitor (Innova 1412, Air Tech Instruments, Ballerup, Denmark) every $20 \mathrm{~min}$. Data were evaluated by analysis of variance by the model in SAS software, version 9.2 (SAS Institute Inc., Cary, NC, USA). The emission rate ( $\mathrm{g}$ per hour) was calculated as follows: $\mathrm{F}$ $=\mathrm{Q} \times\left(\mathrm{C}_{\mathrm{o}}-\mathrm{C}_{\mathrm{i}}\right)$, in which: $\mathrm{F}$ is the emission rate of $\mathrm{CH}_{4}-\mathrm{C}$ ( $\mathrm{g} \mathrm{kg}^{-1} \mathrm{VS}$ per day); $\mathrm{Q}$ is the air flow ( $\mathrm{m}^{3}$ per day); and $\mathrm{C}_{\mathrm{o}}$ and $\mathrm{C}_{\mathrm{i}}$ are the concentrations of the exit gas and the inlet gas $\left(\mathrm{g} \mathrm{m}^{-3} \mathrm{~kg}^{-1} \mathrm{VS}\right)$, respectively. The volatile solids (VS) of swine manure were calculated daily as follows: $\mathrm{VSi}=[\mathrm{VS}$ inputs $] \mathrm{i}-\left[\Sigma_{1}^{\mathrm{i}}\left(\mathrm{VSCO}_{2}+\mathrm{VSCH}_{4}\right)\right]$, in which VSi represents the volatile solids available in

Table 1. Chronogram of slurry loads, and average characteristics of inputs in the pilot scale deposit.

\begin{tabular}{rccccc}
\hline Day & $\begin{array}{c}\text { Volume } \\
(\mathrm{L})\end{array}$ & \multicolumn{4}{c}{ Average characteristics of swine slurry } \\
\cline { 3 - 6 } & & $\begin{array}{c}\mathrm{NH}_{4}-\mathrm{N} \\
\left(\mathrm{mg} \mathrm{L}^{-1}\right)\end{array}$ & $\begin{array}{c}\mathrm{TN} \\
\left(\mathrm{mg} \mathrm{L}^{-1}\right)\end{array}$ & $\begin{array}{c}\mathrm{OC} \\
\left(\mathrm{g} \mathrm{L}^{-1}\right)\end{array}$ & $\begin{array}{c}\mathrm{VS} \\
\left(\mathrm{g} \mathrm{L}^{-1}\right)\end{array}$ \\
\hline 1 & 300 & 1907 & 2949 & 13.91 & 16.54 \\
7 & 300 & 1535 & 2321 & 8.86 & 11.51 \\
14 & 300 & 2499 & 4573 & 25.62 & 29.33 \\
28 & 300 & 2319 & 3770 & 19.54 & 20.83 \\
48 & 100 & 2043 & 2980 & 12.43 & 16.68 \\
55 & 100 & 2371 & 3763 & 19.25 & 22.64 \\
\hline
\end{tabular}

(1) $\mathrm{NH}_{4}-\mathrm{N}$, Ammonium; TN, total nitrogen; OC, organic carbon; VS, volatile solids the deposit in day i; [VS input]i corresponds to the accumulated amount of VS that was introduced in the deposit (manure volume $\times$ VS concentration), through manure loads, at days 1, 7, 14, 28, 48, and 55 (Table 1); and $\left[\Sigma_{1}^{\mathrm{i}}\left(\mathrm{VSCO}_{2}+\mathrm{VSCH}_{4}\right)\right]$ is the accumulated loss of volatile solids mineralized that were and emitted as $\mathrm{CH}_{4}$ and $\mathrm{CO}_{2}$.

Total emission of $\mathrm{CH}_{4}-\mathrm{C}\left(\mathrm{g} \mathrm{kgVS}^{-1}\right)$ during the 180 days of assessment was obtained by the integration of the graphic $\mathrm{F}$ ( $\mathrm{g} \mathrm{kg}^{-1} \mathrm{VS}$ per day) $\mathrm{x}$ time (day), and the resulting curve represents the accumulated $\mathrm{CH}_{4}-\mathrm{C}$ emission over time.

As IPCC Guidelines (Eggleston et al., 2006) estimate methane emission factor in volume $\left(\mathrm{m}^{3}\right)$ instead of mass $(\mathrm{g})$, the unit conversion was made using an ideal gas law: $\mathrm{V}=\mathrm{n} \times \mathrm{R} \times \mathrm{T} / \mathrm{P}$, in which: $\mathrm{V}$ is the gas volume $\left(\mathrm{m}^{3}\right) ; \mathrm{n}$ is number of moles; $\mathrm{R}$ is the gas constant $\left(8.2057 \times 10^{-5} \mathrm{~m}^{3}\right.$ atm $\left.\mathrm{K}^{-1} \mathrm{~mol}^{-1}\right)$; $\mathrm{T}$ is temperature $(\mathrm{K})$; and $\mathrm{P}$ is the pressure in atm.

Data of acccumulated $\mathrm{CH}_{4}-\mathrm{C}$ emission over time, during the slurry storage period, were analyzed using a proper graphing and data analyzing software (Origin Lab, Northampton, MA, USA), and the best fitting equation with the pattern of the resulting graphic was achieved. Subsequently, the consistency of the mathematical model was validated using data collected in a field assay conducted in a real scale slurry deposit, located in the same geographic region, but under contrasting climatic conditions (winter). This assessment was conducted as described below.

The study for manure storage and management was also carried out in the municipality of Concordia, $\mathrm{SC}$, Brazil, during 50 days (June and July). A circular concrete pit $\left(\varnothing_{\text {internal }}=5.0 \mathrm{~m}, \mathrm{~h}=1.8 \mathrm{~m}, \mathrm{v}=35.6 \mathrm{~m}^{3}\right)$ was daily fed over 30 days ( 5 days a week) with aliquots of $1 \mathrm{~m}^{3}$ of fresh manure from a demo farrow-to-finishing operation of 14 sows. Manure sampling and analyses were conducted as previously described in the pilot scale assay, but the characteristics of manure had much higher variability in the field assessment. The chemical characterization of swine slurry loads in field storage $(\mathrm{n}=30)$ was: $\mathrm{NH}_{4}-\mathrm{N}\left(1,840 \pm 570 \mathrm{mg} \mathrm{L}^{-1}\right) ; \mathrm{TN}(2,610 \pm 890$ $\left.\mathrm{mg} \mathrm{L}^{-1}\right)$; OC $\left(33.0 \pm 13.2 \mathrm{~g} \mathrm{~L}^{-1}\right)$; VS $\left(16.0 \pm 7.86 \mathrm{~g} \mathrm{~L}^{-1}\right)$.

The measurement of GHG emissions was performed with a conical dynamic chamber made of transparent PVC film $(\varnothing=5.05 \mathrm{~m} ; \mathrm{h}=1.6 \mathrm{~m})$, installed above the pit, leaving a space of $20 \mathrm{~cm}$ between the concrete margin of the pit and the lower edge of the chamber to 
allow of the entrance of fresh air. An exhaust pipe of $\varnothing=300 \mathrm{~mm}$ was installed on the top of the chamber, and the ventilation rate was fixed at $147 \mathrm{~m}^{3}$ per hour, using a fan equipped with a dimmer. The sampling point for outlet air was located in the exhaust pipe $53 \mathrm{~cm}$ before the fan, while the samples of inlet air (fresh air) were collected in two opposite points right below the lower edge of the chamber. Similarly to the pilot experiment, samples were continuously - every $2 \mathrm{~min}$ for each sampling point - and automatically pumped to the measurement device (Innova 1313/Innova 1412, Air Tech Instruments, Ballerup, Denmark) - through Teflon tubes of $4 \mathrm{~mm}$ diameter placed in the sampling points during the 50 days of assessment.

The emission rate and accumulated emission were calculated as previously described in the pilot assay, and the resulting curve was compared to the one obtained by the mathematical model.

\section{Results and Discussion}

A high variability was observed in daily average $\mathrm{CH}_{4}$-C emission througout 180 days (Figure $1 \mathrm{~A}$ ). Nevertheless, after the last charge of slurry at $55^{\text {th }}$ day, there was a gradual increase of the emission rate, followed by a steep increase in $110-130^{\text {th }}$ days, and finally an abrupt reduction. The lower emission at the beginning occurred because of both the lag time for anaerobic biological system establishment and the floating crust that partially covered the emitting surface. As the organic matter degradation proceeded, there was a moment when the physical barrier constituted by the crust was breached, resulting in a sudden $\mathrm{CH}_{4}$ release that was dammed in the liquid column, once the trapped $\mathrm{CH}_{4}$ was emitted, the flow rapidly decreased.

The accumulated $\mathrm{CH}_{4}-\mathrm{C}$ emission along the manure storage period (Figure 1 B) was obtained from the integration of daily average emission data (Figure $1 \mathrm{~A}$ ). Therefore, throughout the 180 days of monitoring, the slurry deposit emitted $242.8 \mathrm{~g} \mathrm{CH}_{4}-\mathrm{C} \mathrm{kg}^{-1} \mathrm{VS}$, which was converted to volume using the ideal gas law. As the curve of Figure $1 \mathrm{~B}$ reached a plateau in the $130^{\text {th }}$ day, we assumed that labile carbon content of slurry was totally consumed, and, thus, the resulting value could be expressed as the methane emission factor $\mathrm{B}_{0}=0.48 \mathrm{~m}^{3} \mathrm{~kg}^{-1} \mathrm{VS}$ of the stored slurry. This result is in agreement with a recent review that reported values of $\mathrm{B}_{0}$ varying from 0.29 to $0.53 \mathrm{~m}^{3} \mathrm{~kg}^{-1} \mathrm{VS}$ (Philippe \& Nicks, 2015).

According to IPCC Guidelines (Eggleston et al., 2006), the $\mathrm{B}_{0}$ for manure management in Latin America is estimated as $0.29 \pm 0.04 \mathrm{~m}^{3} \mathrm{CH}_{4} \mathrm{~kg}^{-1} \mathrm{VS}$, whilst in Europe and the USA $\mathrm{B}_{0}$ are $0.45 \pm 0.07 \mathrm{~m}^{3} \mathrm{CH}_{4}$ $\mathrm{kg}^{-1} \mathrm{VS}$ and $0.48 \pm 0.08 \mathrm{~m}^{3} \mathrm{CH}_{4} \mathrm{~kg}^{-1} \mathrm{VS}$, respectively. Therefore, $\mathrm{B}_{0}$ found in the present study was closer to the European and American values than the Latin American one. This may occur because this work was conducted in a region where livestock production is highly industrialized, and Santa Catarina state is one of the main Brazilian pork meat exporter. Consequently,
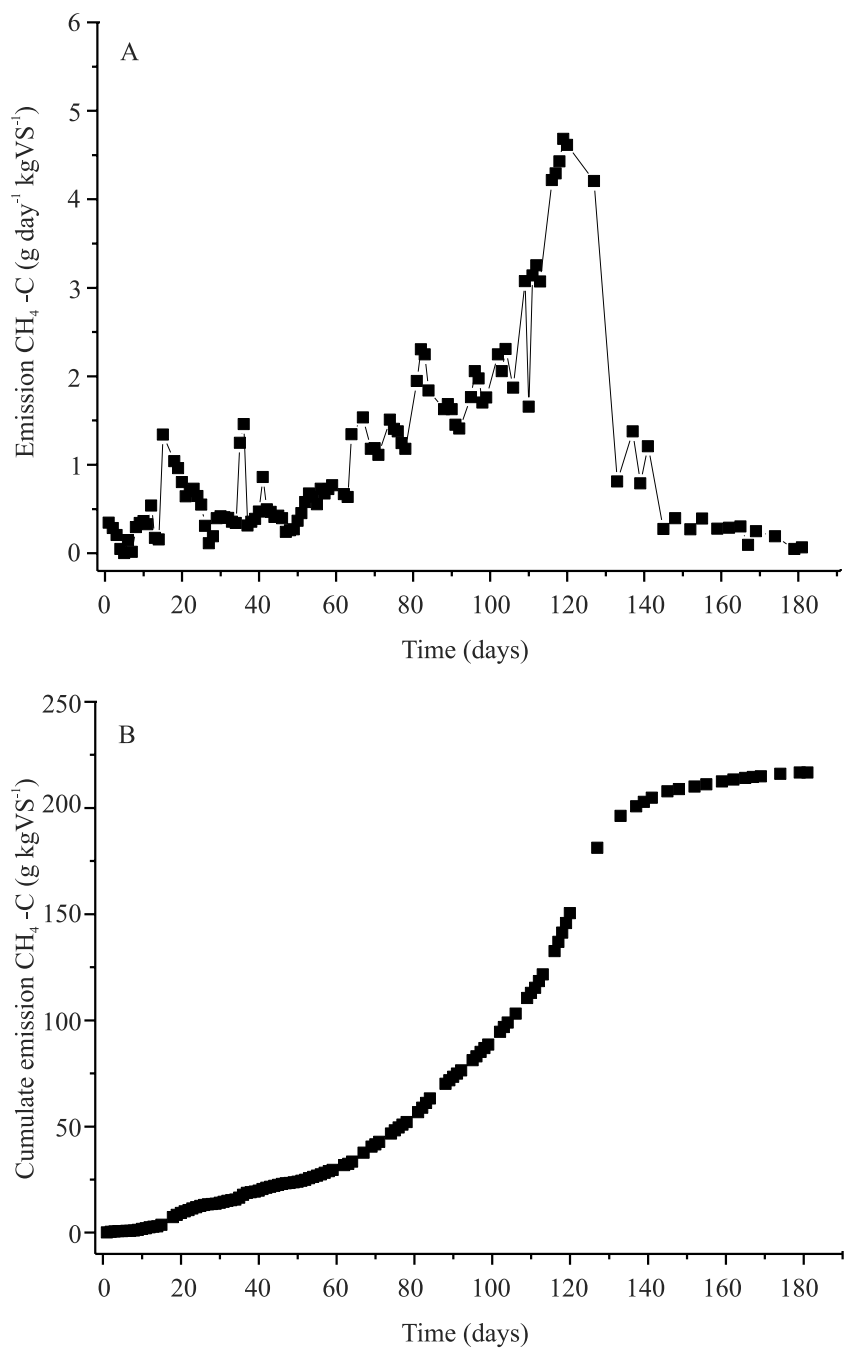

Figure 1. Average daily emission (A), and acccumulated emission of $\mathrm{CH}_{4}-\mathrm{C}$ from swine slurry storage throughout the 180 days of monitoring (B). 
in order to meet the quality standards required by the international market, the production systems, feed, and animal genetics that prevails in Santa Catarina do not differ greatly from the ones adopted by main competitors worldwide.

Nonetheless, swine production in Brazil is very heterogeneous, for instance, in the North and Northeast regions (18\% of the country's herd), the subsistence production is still very significant, whereas in the Southeast and Center-West regions $(28 \%$ of the country's herd) the high dilution of manure resulting from the excess water usage may imply in lower $\mathrm{CH}_{4} /$ $\mathrm{CO}_{2}$ emission ratio, according to Miele et al. (2013). Therefore, at present, $\mathrm{B}_{0}=0.48 \mathrm{~m}^{3} \mathrm{CH}_{4} \mathrm{~kg}^{-1} \mathrm{VS}$ is the value that could probably be used only in Southern Brazil (54\% of swine herd). However, there is a trend that the model currently adopted in the South be spread to other regions, considering the expansion of the industrial meat production, and the increasingly concern about hydric deficit.

Therefore, new approaches are required to mitigate atmospheric impact of manure management. Beside the adoption of treatment technologies, such as anaerobic digester and composting (included in the ABC Program), a promising strategy to lower $\mathrm{CH}_{4}$ emission which did not require any investment is the shortening of the storage time. According to Chadwick et al. (2011), frequent removal of slurry from the store reduces the pool of methanogenic bacteria, and $\mathrm{CH}_{4}-\mathrm{C}$ emission can be lowered by $40 \%$.

The higher emission of $\mathrm{CH}_{4}$ from the slurry deposit was observed from the $60^{\text {th }}$ day on (Figure $1 \mathrm{~B}$ ). Hence, by reducing the storage time, and anticipating the application of manure to agricultural soil, it would be possible to shift the conversion of part of the organic matter (that originally would produce methane) to carbon dioxide, as soil environment favors aerobic biodegradation (Grave et al., 2015).

Climatic conditions in most part of Brazilian territory favor crop production - either grain crops rotation, or pasture - during the whole year, according to Salton et al. (2014); consequently, the storage period could be shortened with a minimum risk of environmental contamination, as long as the capacity of nutrients absorption of each crop is respected, following the principles of conservation agriculture (Balota et al., 2014).
Moreover, Santa Catarina state's environmental law that regulates livestock operations was recently modified; the previous one used to require 120 days as a minimum time for swine slurry storage. However, according to the current law - IN 11 (Santa Catarina, 2014) -, this period will depend on the specific agronomic plan elaborated to each farm, although a minimum storage time of 40 days should be respected. Therefore, it would be possible to shortening the storage period from 120 days to approximately 50 days, considering 7-10 days of grazing.

Mathematical models that estimate gaseous emissions can improve the comprehension of the kinetics of carbon and nutrient losses, and may be a useful tool to support the choice of a specific treatment in detriment of another, or to establish best practices for manure management by optimizing its storage and use as fertilizer.

As $\mathrm{CH}_{4}$ emission from the slurry storages reached a plateau approximately after 130 days (Figure $1 \mathrm{~B}$ ), the model was adjusted in the interval from 0 to 120 days. Accumulated $\mathrm{CH}_{4}$ emission graphic fits a sigmoidal model expressed as follows:

Data adjust resulted in a correlation coefficient $\mathrm{r}^{2}=$ 0.997 for the parameter values of $A_{1}=-12.23 \pm 2.86 ; A_{2}$ $=2165.87 \pm 2763.41 ; \mathrm{x}_{0}=221.08 \pm 73.07 ; \mathrm{dx}=46.16 \pm 4.27$.

By limiting the focus in the first 50 days, it was noticed that the error of the model was diluted as emission proceeded (Figure $2 \mathrm{~B}$ ). Therefore, in the interval from 30 to 40 days, the average error was $8.5 \%$, whereas from 40 to 50 days it dropped to $2.7 \%$. The season of the year and the intervals of slurry loads had no significant effect on methane emission. This may have occurred because the lower temperature during Brazilian winter, even in the southern region, is not sufficient to decrease the manure temperature in the large-volume deposit to $\mathrm{T}<20^{\circ} \mathrm{C}$, which would inhibit methanogenic activities. Besides, a previous study of pyrosequencing analyses, conducted in two independent field scale manure deposits, in farms located in western Santa Catarina state, reported that both microorganism communities composition had similar bacteria diversity (Silva et al., 2015).

According to the mathematical model, by adopting 50 days, instead of 120 days of storage time, up to $83 \%$ of the carbon from the labile organic matter that originally would be converted into methane would be available to be degraded in the soil, where

Pesq. agropec. bras., Brasília, v.53, n.6, p.657-663, June 2018 DOI: $10.1590 / \mathrm{S} 0100-204 \mathrm{X} 2018000600001$ 

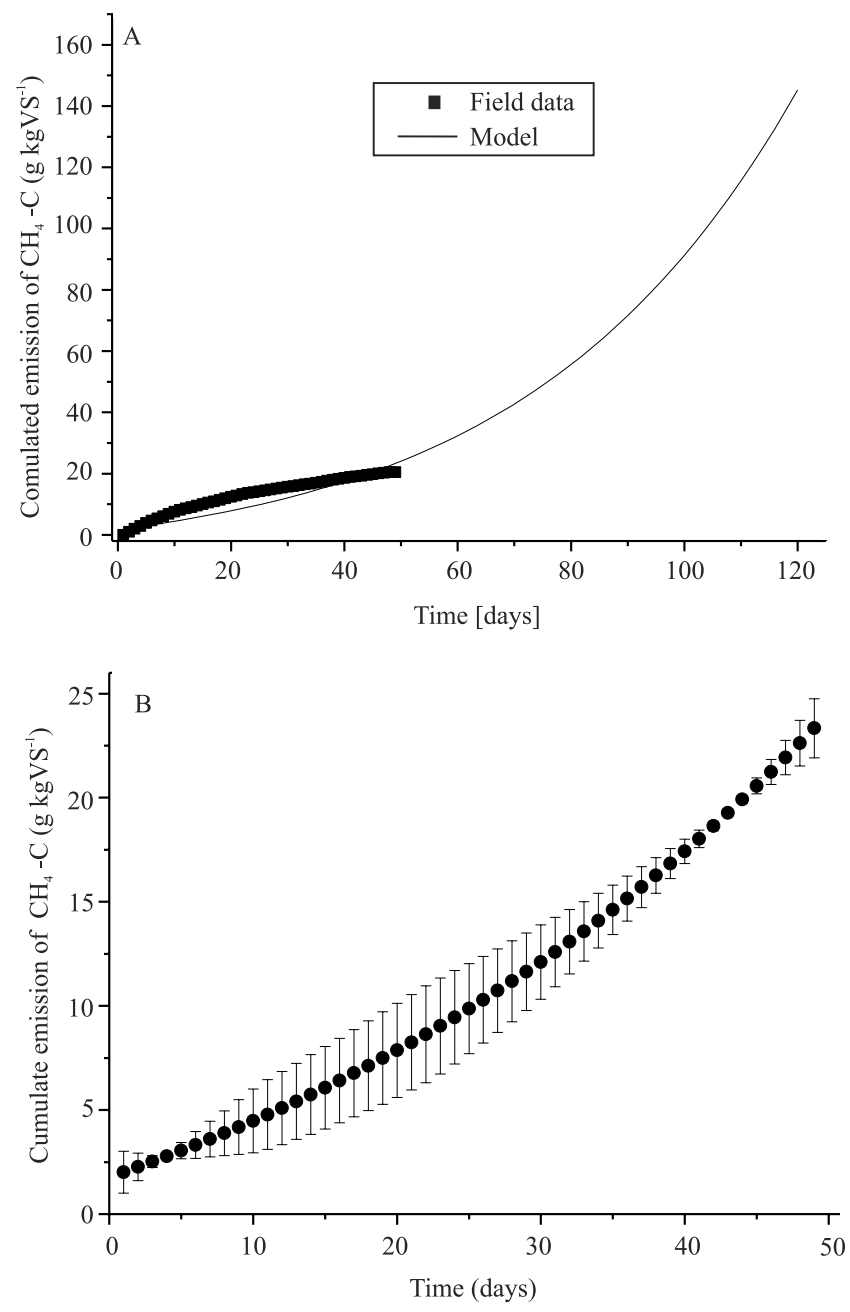

Figure 2. Comparison between the graphic generated by the model and data collected in a swine slurry deposit under field conditions (A), and graphic of the mathematical model with the error bars corresponding to the field-collected data (B).

$\mathrm{CO}_{2}$ emission prevails. Nonetheless, as the resulting fertilizer would have a higher-nitrogen content, new strategies regarding mitigation of nitrogen losses from soil should be evaluated, encompassing application methods (Lovanh et al., 2010; Velthof \& Mosquera, 2011) and chemical and biological additives (VanderZaag et al., 2011; Aita et al., 2014), taking into account a broader approach of the pig production chain, in order to consider the synergic and antagonist effect of introducing new technologies for the animal production emission factor.

\section{Conclusions}

1. The methane emission factor for the baseline scenario of swine manure management adopted by industrial herd in South of Brazil (storage in open deposit) was $\mathrm{B}_{0}=0.48 \mathrm{~m}^{3} \mathrm{~kg}^{-1} \mathrm{VS}$.

2. The methane emission follows a sigmoidal kinetic model, according to which by reducing the storage time from 120 to 50 days, $83 \%$ of originally emitted $\mathrm{CH}_{4}$ would be available in the effluent as organic matter to be fixed or mineralized as $\mathrm{CO}_{2}$ by soil microorganisms.

\section{Acknowledgments}

To Coordenação de aperfeiçoamento de Pessoal de Nível Superior (Capes ), for scholarship granted; and to Pecuária Sustentável (Pecus) and Tecnologias para Produção e Uso de Biogás e Fertilizantes, a partir do tratamento de Dejetos Animais no Âmbito do Plano ABC (Biogasfert), for financial support.

\section{References}

AITA, C.; GONZATTO, R.; MIOLA, E.C.C.; SANTOS, D.B. dos; ROCHETTE, P.; ANGERS, D.A.; CHANTIGNY, M.H.; PUJOL, S.B.; GIACOMINI, D.A.; GIACOMINI, S.J. Injection of dicyandiamide-treated pig slurry reduced ammonia volatilization without enhancing soil nitrous oxide emissions from no-till corn in Southern Brazil. Journal of Environmental Quality, v.43, p.789-800, 2014. DOI: 10.2134/jeq2013.07.0301.

AMERICAN PUBLIC HEALTH ASSOCIATION. Standard methods for the examination of water and wastewater. $20^{\text {th }}$ ed. Washington: American Public Health Association, 1998. 1496p.

ANGELO, C. Brazil's fund for low-carbon agriculture lies fallow. 2012. Available at: <http://www.nature.com/news/brazils-fund-for-low-carbon-agriculture-lies-fallow-1.11111>. Accessed on: June 62015.

BALOTA, E.L.; MACHINESKI, O.; HAMID, K.I.A; YADA, I.F.U.; BARBOSA, G.M.C.; NAKATANI, A.S.; COYNE, M.S. Soil microbial properties after long-term swine slurry application to conventional and no-tillage systems in Brazil. Science of the Total Environment, v.490, p.397-404, 2014. DOI: 10.1016/j. scitotenv.2014.05.019.

BRAZIL. GENERAL-COORDINATION ON GLOBAL CLIMATE CHANGE. Second National Communication of Brazil to the United Nations Framework Convention on Climate Change. Brasília: MCT, 2010. 264p.

BROWN, S.; KRUGER, C.; SUBLER, S. Greenhouse gas balance for composting operations. Journal of Environment Quality, v.37, p.1396-1410, 2008. DOI: 10.2134/jeq2007.0453. 
CARDOSO, A.S.; BERNDT, A.; LEYTEM, A.; ALVES, B.J.R.; CARVALHO, I. das N.O. de; SOARES, L.H. de B.; URQUIAGA, S.; BODDEY, R.M. Impact of the intensification of beef production in Brazil on greenhouse gas emissions and land use. Agricultural Systems, v.143, p.86-96, 2016. DOI:10.1016/j.agsy.2015.12.007.

CHADWICK, D.; SOMMER, S.; THORMAN, R.; FANGUEIRO, D.; CARDENAS, L.; AMON, B.; MISSELBROOK, T. Manure management: implications for greenhouse gas emissions. Animal Feed Science and Technology, v.166-167, p.514-531, 2011. DOI: 10.1016/j.anifeedsci.2011.04.036.

CHERUBINI, E.; ZANGHELINI, G.M.; ALVARENGA, R.A.F.; FRANCO, D.; SOARES, S.R. Life cycle assessment of swine production in Brazil: a comparison of four manure management systems. Journal of Cleaner Production, v.87, p.68-77, 2015. DOI: 10.1016/j.jclepro.2014.10.035.

DENNEHY, C.; LAWLOR, P.G.; JIANG, Y.; GARDINER, G.E.; XIE, S.; NGHIEM, L.D.; ZHAN, X. Greenhouse gas emissions from different pig manure management techniques: a critical analysis. Frontiers of Environmental Science \& Engineering, v.11, art.11, 2017. DOI: 10.1007/s11783-017-0942-6.

GODBOUT, S.; VERMA, M.; LAROUCHE, J.P.; POTVIN, L.; CHAPMAN, A.M.; LEMAY, S.P.; PELLETIER, F.; BRAR, S.K. Methane production potential $\left(\mathrm{B}_{0}\right)$ of swine and cattle manures - a Canadian perspective. Environmental Technology, v.31, p.1371-1379, 2010. DOI: 10.1080/09593331003743096.

GRAVE, R.A.; NICOLOSO, R. da S.; CASSOL, P.C.; AITA, C.; CORRÊA, J. C.; DALLA COSTA, M.; FRITZ, D.D. Shortterm carbon dioxide emission under contrasting soil disturbance levels and organic amendments. Soil \& Tillage Research, v.146, p.184-192, 2015. DOI: 10.1016/j.still.2014.10.010.

EGGLESTON, S.; BUENDIA, L.; MIWA, K.; NGARA, T.; TANABE, K. (Ed.). 2006 IPCC Guidelines for National Greenhouse Gas Inventories: volume 4: Agriculture, Forestry and Other Land Use. Hayama: IPCC, 2006. 83p.

KUNZ, A.; MIELE, M.; STEINMETZ, R.L.R. Advanced swine manure treatment and utilization in Brazil. Bioresource Technology, v.100, p.5485-5489, 2009. DOI: 10.1016/j. biortech.2008.10.039.

LAGUË, C. Management practices to reduce greenhouse gas emissions from swine production systems. In: BALL, R.O. (Ed.). Advances in pork production. Alberta: University of Alberta, 2003. v.14, p.287-300.

LOVANH, N.; WARREN, J.; SISTANI, K. Determination of ammonia and greenhouse gas emissions from land application of swine slurry: a comparison of three application methods. Bioresource Technology, v.101, p.1662-1667, 2010. DOI: 10.1016/j. biortech.2009.09.078.

MIELE, M.; ALMEIDA, M.M.T.B.; MONTICELLI, C.J.; OLIVEIRA, O.C. de; BOFF, J.A.; PALHARES, J.C.P.; SANDI,
A.J.; CARDOSO, L.S. Caracterização da suinocultura no Brasil a partir do Censo Agropecuário 2006 do IBGE. Concórdia: Embrapa Suínos e Aves, 2013. 149p. (Embrapa Suínos e Aves. Documentos, 160).

PHILIPPE, F.-X.; NICKS, B. Review on greenhouse gas emissions from pig houses: production of carbon dioxide, methane and nitrous oxide by animals and manure. Agriculture, Ecosystems and Environment, v.199, p.10-25, 2015. DOI: 10.1016/j. agee.2014.08.015.

RIAÑO, B.; GARCÍA-GONZÁLEZ, M.C. Greenhouse gas emissions of an on-farm swine manure treatment plant comparison with conventional storage in anaerobic tanks. Journal of Cleaner Production, v.103, p.542-548, 2015. DOI: 10.1016/j. jclepro.2014.07.007.

SAFELY, L.M.; CASADA, M.E.; WOODBURY, J.W.; ROOS, K.F. Global Methane Emissions from Livestock and Poultry Manure. Washington: EPA, 1992. 221p. EPA/400/1-91/048.

SALTON, J.C.; MERCANTE, F.M.; TOMAZI, M.; ZANATTA, J.A.; CONCENÇO, G.; SILVA, W.M.; RETORE, M. Integrated crop-livestock system in tropical Brazil: toward a sustainable production system. Agriculture, Ecosystems and Environment, v.190, p.70-79, 2014. DOI: 10.1016/j.agee.2013.09.023.

SANTA CATARINA. FUNDAÇÃO DO MEIO AMBIENTE DE SANTA CATARINA. Instrução Normativa no 11 Suinocultura. 2014. Available at: <http://www.fatma.sc.gov.br/ conteudo/instrucoes-normativas >. Accessed on: Sept. 212015.

SILVA, M.L.B. da; CANTÃO, M.E.; MEZZARI, M.P.; MA, J.; NOSSA, C.W. Assessment of bacterial and archaeal community structure in swine wastewater treatment processes. Microbial Ecology, v.70, p.77-87, 2015. DOI: 10.1007/s00248-014-0537-8.

TAUSEEF, S.M.; PREMALATHA, M.; ABBASI, T.; ABBASI, S.A. Methane capture from livestock manure. Journal of Environmental Management, v.117, p.187-207, 2013. DOI: 10.1016/j.jenvman.2012.12.022.

VANDERZAAG, A.C.; JAYASUNDARA, S.; WAGNERRIDDLE, C. Strategies to mitigate nitrous oxide emissions from land applied manure. Animal Feed Science and Technology, v.166-167, p.464-479, 2011. DOI: 10.1016/j.anifeedsci.2011.04.034.

VELTHOF, G.L.; MOSQUERA, J. The impact of slurry application technique on nitrous oxide emission from agricultural soils. Agriculture, Ecosystems and Environment, v.140, p.298-308, 2011. DOI: 10.1016/j.agee.2010.12.017.

ZEEMAN, G.; GERBENS, S. $\mathrm{CH}_{4}$ emissions from animal manure. In: IPCC. Intergovernmental Panel on Climate Change. IPCC Expert Meetings on Good Practice Guidance and Uncertainty Management in National Greenhouse Gas Inventories. [Hayama]: IPCC, 2000. p.339-348. (IPCC Background Papers).

Received on July 15, 2016 and accepted on September 27, 2017 